INFO ARTIKEL

Riwayat Artikel:

Diterima : 05 Mei 2018

Disetujui : 22 Agustus 2018

\title{
GEOGRAFI
}

\section{RESISTENSI PEDAGANG TERHADAP RELOKASI PASAR TRADISIONAL DI KELURAHAN MARIANA KECAMATAN BANYUASIN 1 KABUPATEN BANYUASIN}

\author{
Sevti Andreasmi ${ }^{1}$, Budi Utomo ${ }^{2}$ \\ ${ }^{1}$ Guru Mengadi Kabupaten Muara Enim, Provinsi Sumatera Selatann, \\ ${ }^{2}$ Pendidikan Geografi, Universitas PGRI Palembang, \\ ( $\square)$ sandreasmi@gmail.com ${ }^{1}$
}

\begin{abstract}
ABSTRAK
Masalah dalam penelitian ini adalah bagaimana resistensi pedagang terhadap relokasi pasar tradisional di Kelurahan Mariana Kecamatan Banyuasin 1 Kabupaten Banyuasin. Tujuan penelitian ini untuk mengetahui resistensi pedagang terhadap relokasi pasar tradisional di Kelurahan Mariana Kecamatan Banyuasin 1 Kabupaten Banyuasin. Metode penelitian yang digunakan ialah metode kualitatif. Sumber data penelitian ini adalah pedagang pasar atau penjual dan pemerintahan setempat yaitu ketua LPM (Lembaga Pemberdayaan Masyarakat) dengan jumlah informan 7 orang. Teknik analisis data dalam penelitian ini menggunakan reduksi data, penyajian data, dan kesimpulan. Hasil penelitian ini dilihat dari Karakter pedagang yang paling mempengaruhi keputusan pedagang untuk menolak relokasi pasar tradisional di Kelurahan Mariana yaitu tingkat pendidikan para pedagang yang mayoritas lulusan Sekolah Menengah Atas (SMA), tingkat pendidikan itulah yang mempengaruhi pola fikir para pedagang. Faktor lain yang mempengaruhi resistensi pedagang terhadap relokasi yaitu anggaran dana, pemerintah tidak menyediakan biaya relokasi dari pasar lama dan pasar baru. Hal ini menjadi hambatan dalam relokasi pasar sehingga menolak untuk relokasi pasar tersebut. Setelah itu dalam Infastruktur dilihat dari tempat yang telah disediakan oleh Pemerintah bagi pedagang yang direlokasi, akan tetapi untuk Akses transportasi disana belum memadai dikarenakan tidak ada angkutan umum untuk menuju ke lokasi pasar tersebut. Jadi para pedagang lebih memilih tetap berdagang di pasar yang lokasinya dekat dengan pemukiman.
\end{abstract}

Kata kunci: Resistensi Pedagang, Relokasi Pasar, Pasar Tradisional.

\section{PENDAHULUAN}

Sumber perekonomian di Indonesia itu berasal dari sektor informal contohnya pertumbuhan industri membuat berkembangnya kebutuhan akan pakaian, makanan, tempat tinggal dan lain sebagainya. Salah satu sektor informal yang cukup memberikan kontribusi besar itu adalah pasar (Dewi, 2015). Pasar yang merupakan suatu tempat bertemunya penjual dan pembeli dalam satu lokasi dan melakukan transaksi jual beli baik itu barang maupun jasa. Dibeberapa bidang pekerjaan yang termasuk dalam sektor informal, yang paling menonjol aktifitasnya adalah para pedagang di pasar. Perkembangan pembangunan di Kabupaten Banyuasin dan pertumbuhan jumlah penduduk yang semakin bertambah.

Selain mengakibatkan meningkatnya konsumsi masyarakat terhadap barang dagangan kebutuhan rumah tangga, juga berpengaruh terhadap pelaksanaan Pengelolaan Pasar di Wilayah Kabupaten Banyuasin terutama di Kelurahan Mariana Kecamatan Banyuasin 1. Pasar 
Pagi Lorong Milik merupakan salah satu pasar tradisional yang terdapat di wilayah Kelurahan Mariana Kecamatan Banyuasin 1 yang buka dari pagi hingga ke siang hari. Pasar ini terpusat didaerah Kecamatan dengan akses yang lebih mudah dan ditinjau dari segala hal ini lebih mudah para penjual untuk menjual dagangannya di pasar Pagi Lorong Milik.

Akan tetapi pasar tersebut memiliki lahan yang cukup sempit karena berada di dalam lorong sehingga sering terjadinya kemacetan di jalan Sabar Jaya selain itu juga masih kurangnya fasilitasfasilitas yang ada disana seperti toilet umum. Seharusnya, pasar membutuhkan lahan dan lokasi yang strategis, mengingat aktivitas yang terjadi di pasar tersebut dan pentingnya peran pasar sebagai salah satu komponen pelayanan kota, desa dan wilayah yang mengakibatkan kaitan dan pengaruh dari masing-masing unsur penunjang kegiatan perekonomian kota dan desa. Hal ini sama dengan pemikiran (Suryani, 2015) bahwa dalam hal pemilihan lokasi pembangunannya, pasar tradisional sebaiknya didirikan pada lokasi yang ramai dan luas, agar lebih terjamin proses transaksi jual beli sehingga dapat diperhatikan faktor-faktor keramaian lalu lintas, kemungkinan tempat pemberhentian orang untuk berbelanja, keadaan penduduk di lingkungan pasar, keadaan perparkiran dan sebagainya (Utomo, 2017).

Faktor penghambat mengenai kebijakan relokasi itu berasal dari pihak terkait pembuat implementasi jika dilihat dari fenomena di atas, dimana belum ada persiapan yang matang untuk melakukan sebuah relokasi pasar, disamping itu juga masyarakat sebagai penerima sebuah kebijakan apakah menyetujui atau menolak dalam permasalahan relokasi pasar ini karena masyarakat ini berpengaruh dalam kebijakan yang dibuat oleh pemerintah. Maka dari itu pemerintah setempat akan melakukan penertiban dalam pengelolaan pasar yang akan merelokasi pasar yang berada di kelurahan Mariana ke kelurahan Perajin.

Akan tetapi para pedagang menolak rencana relokasi pasar tersebut dengan alasan pertimbangan ekonomi dimana lokasi relokasi pasar yang baru tidak strategis sehingga mempengaruhi pendapatan para pedagang, sampai saat ini pasar yang baru yang tak kunjung di tempati oleh para pedagang sehingga bangunan yang telah di sediakan oleh pemerintah sebagai lokasi untuk merelokasi pasar sudah mulai rusak dan tidak terawat karena para pedagang tetap berjualan di pasar pagi Lorong Milik kelurahan Mariana. Penolakan ini senada dengan penelitian yang di teliti oleh (Dewi, 2015) bahwasannya lokasi pasar baru yang telah disediakan oleh pemerintah daerah itu tidak strategis dan para pedagang merasa bahwa pendapatan yang di dapat tidak sebanyak ketika berada di lokasi pasar lama, menurut Djojodipuro (dalam Suryani, 2015) yaitu dalam hal pemilihan lokasi pembangunannya, pasar tradisional sebaiknya didirikan pada lokasi yang ramai dan luas. Pendirian pasar pada lokasi yang tidak ada aktivitas perdagangannya, sangat sulit diharapkan akan dikunjungi oleh masyarakat. Terkait mengenai pendapatan Menurut Harun untuk menetapkan dasar pemilihan lokasi industri dengan mempertimbangkan biaya dan pendapatan. Variasi spasial dalam total biaya dan total pendapatan dapat memunculkan lokasi optimum dengan keuntungan maksimum, dan dalam keadaan margin spasial tidak memberikan keuntungan maka perusahaan bebas berlokasi di sembarang tempat, sehingga maksimisasi keuntungan bukan lagi merupakan tuntutan. Suatu posisi dalam margin keuntungan yang bervariasi, secara umum sangat diperlukan dalam penetapan lokasi industri yang direncanakan. Pentingnya penelitian ini untuk menjelaskan tentang apa yang menjadi alasan utama munculnya resistensi yang dilakukan oleh para pedagang pasar terhadap relokasi pasar pagi Lorong Milik itu sendiri.

\section{METODE PENELITIAN}

Adapun Penelitian ini, peneliti menggunakan jenis penelitian deskriptif kualitatif. Lokasi penelitian dilaksanakan di pasar pagi di Kelurahan Mariana Kecamatan Banyuasin 1 Kabupaten Banyuasin. Peta lokasi dapat dilihat pada gambar 1.

Informan dalam penelitian terdapat 2 informan yaitu :

a) Informan Utama yang meliputi pengguna pasar ( penjual atau pedagang di sekitar pasar pagi Kelurahan Mariana.

b) Informan kunci yang meliputi (pengelola pasar pagi di Kelurahan Mariana dan 
Pemerintahan setempat.

Sumber data primer adalah sumber data yang langsung memberikan data kepada pengumpul data. Dalam penelitian ini sumber data primer yang akan peneliti peroleh melalui wawancara terhadap pedagang pasar atau penjual dan pemerintahan setempat yaitu ketua LPM (Lembaga Pemberdayaan Masyarakat). Sumber data sekunder adalah sumber yang tidak langsung memberikan

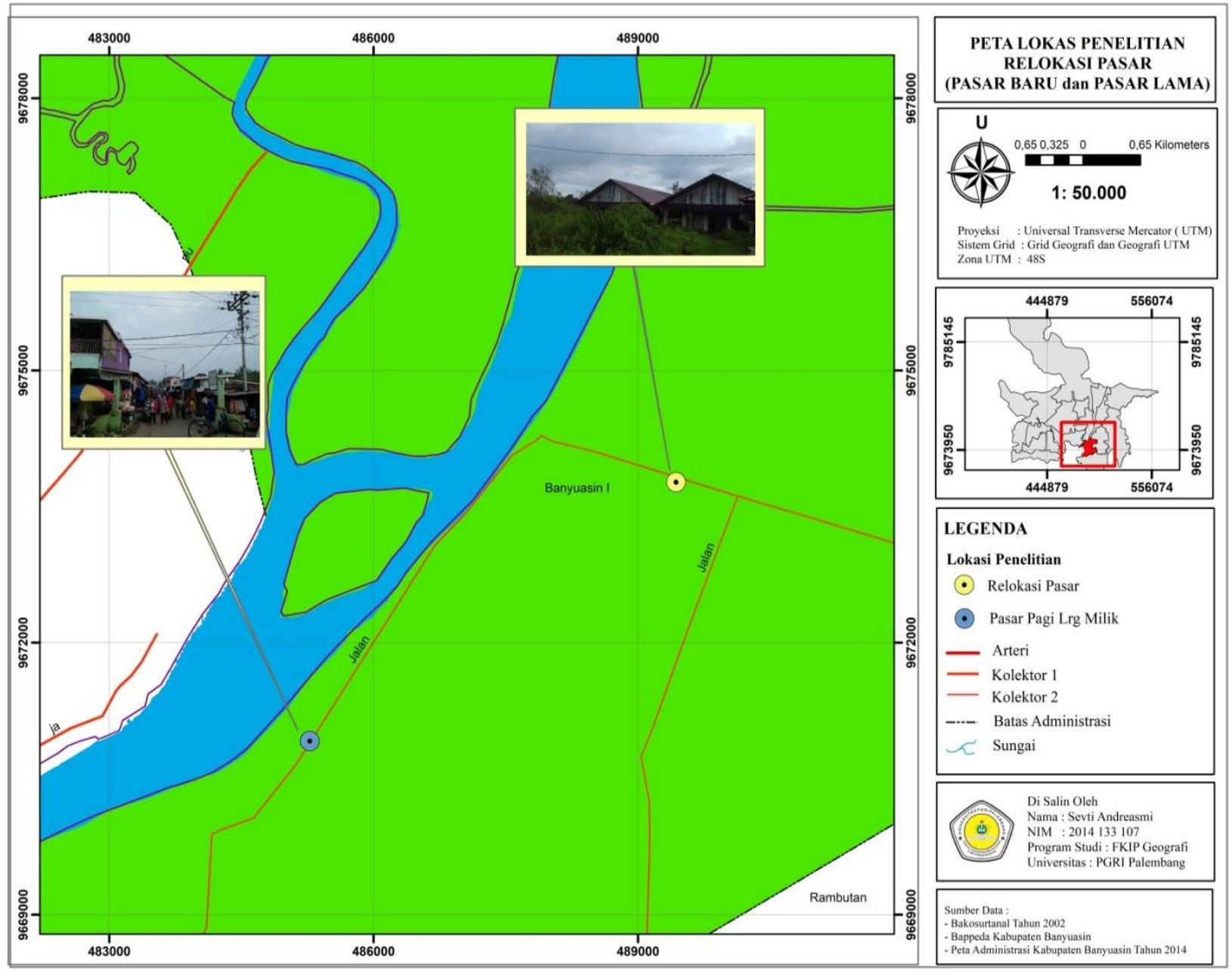

Gambar 1. Lokasi Penelitian

data kepada pengumpul data, misalnya lewat orang lain atau lewat dokumen. Dalam penelitian ini sumber data sekunder yang akan peneliti peroleh dari berbagai buku, tulisan dan karangan dari pengarang lain yang terkait dengan penelitian tersebut.

Dokumentasi adalah teknik pengumpulan data yang tidak langsung ditujukan pada subjek penelitian, tetapi yang isinya merupakan pernyataan tertulis yang disusun oleh seseorang atau lembaga untuk keperluan pengujian suatu peristiwa, dan berguna bagi sumber data, bukti, infromasi, kealamiahan yang sukar diperoleh dan ditemukan, dan membuka kesempatan untuk lebih memperluas pengetahuan terhadap sesuatu yang diselidiki menurut Sedarmayanti (dalam Mahmud,
2011). Dalam melaksanakan metode dokumentasi, peneliti meneliti berbagai aktifitas pengguna pasar tersebut berupa gambar pasar lorong milik dan pasar yang akan di relokasi.

Observasi merupakan teknik pengamatan dan pencatatan sistematis dari fenomena-fenomena yang diselidiki. Dalam penelitian ini observasi yang dilakukan peneliti yaitu mengamati keadaan pasar baik itu pasar lama (lorong milik) dan pasar yang akan di relokasi.

Wawancara digunakan sebagai teknik pengumpulan data apabila peneliti ingin melakukan studi pendahuluan untuk menemukan permasalahan yang harus diteliti, dan juga apabila peneliti ingin mengetahui hal-hal dari responden yang lebih mendalam dan jumlah responden nya 
sedikit /kecil, dalam penelitian ini wawancara di lakukan kepada pengguna pasar (penjual, pembeli), penjaga parkir, masyarakat sekitar pasar pagi di Kelurahan Mariana dan pengelola pasar serta pemerintahan setempat (LPM atau Lembaga Pemberdayaan Masyarakat).

Menurut Moleong dalam Sedarmayanti dan Hidayat menyatakan bahwa sesuatu yang didengar, dilihat, dialami, dan dipikirkan dalam rangka pengumpulan data dan refleksi terhadap data dalam penelitian kualitatif guna untuk memperoleh gambaran konkrit tentang kejadian di lapangan. Penelitian ini dilakukan untuk mengutarakan kondisi pasar pagi Lorong Milik berupa tulisan, gambar dan peta.

Penelitian ini menggunakan metode penelitian kualitatif dan model interaktif. Dalam Model Interaktif ada tiga kopmponen kegiatan yang terjadi secara bersamaan, tiga komponen tersebut adalah reduksi data, penyajian data, dan kesimpulan Miles dan Huberman (dalam Sugiyono, 2010).

\section{HASIL DAN PEMBAHASAN}

Setelah peneliti melakukan wawancara dan observasi kepada para pedagang dan pemerintahan setempat, data dianalisis dengan menggunakan penelitian kualitatif dengan model Miloes dan Huberman, penelitian dilakukan pada saat pengumpulan data berlangsung, dan setelah selesai pengumpulan data dalam periode tertentu. Pada saat wawancara, peneliti sudah melakukan analisis terhadap jawaban yang akan diwawancarai. Bila jawaban yang diwawancarai setelah dianalisis terasa belum memuaskan, maka peneliti akan melanjutkan pertanyaan, sampai tahap tertentu, diperoleh data yang dianggap kredibel menurut Miles dan Huberman (dalam Sugiyono,2010).

Hasil penelitian yang diperoleh dari karakteristik pedagang yang meliputi jenis kelamin, umur, agama dan pendidikan para pedagang menjelaskan bahwa tingkat pendidikan para pedagang rata- rata Sekolah Menengah Atas (SMA) sedangkan Agama informan dan pedagang mayoritas Islam dan jenis kelamin para informan yaitu perempuan, serta rata-rata umur informan berkisar > 50tahun, dari karakteristik pedagang inilah yang mempengaruhi keputusan resistensi para pedagang terhadap relokasi pasar tersebut.

Karakter pedagang yang paling mempengaruhi keputusan pedagang untuk menolak relokasi pasar tradisional di Kelurahan Mariana yaitu tingkat pendidikan para pedagang yang mayoritas lulusan Sekolah Menengah Atas (SMA), tingkat pendidikan itulah yang mempengaruhi pola fikir para pedagang dimana para pedagang berpikir bahwa ditempat yang baru mereka tidak mampu memperoleh pendapatan sama seperti di pasar lama di karenakan pasar baru perlu beradaptasi dan juga jauh dari permukiman serta tidak ada akses transportasi umum untuk menuju lokasi pasar.

Faktor lain yang mempengaruhi resistensi pedagang terhadap relokasi yaitu anggaran dana, pemerintah tidak menyediakan biaya relokasi dari pasar lama dan pasar baru. Hal ini menjadi hambatan dalam relokasi pasar sehingga menolak untuk di relokasi pasar tersebut. Untuk terlaksananya relokasi pasar sebaiknya para pedagang itu diberi anggaran dana sebagai faktor pendorong keberhasilan dalam pelaksanaan relokasi pasar ini, hal ini sama dengan pemikiran Hidayah, 2017 yang menyatakan bahwa dalam pelaksanaan relokasi pasar, anggaran menjadi faktor pendukung keberhasilan kegiatan. Tidak hanya anggaran yang memadai untuk persiapan pelaksanaan relokasi, namun juga untuk memberikan dana bantuan pemindahan kepada para pedagang.

Setelah itu dalam Infastruktur dilihat dari tempat yang telah disediakan oleh Pemerintah bagi pedagang yang direlokasi, akan tetapi untuk akses transportasi disana belum memadai dikarenakan tidak ada angkutan umum untuk menuju ke lokasi pasar tersebut. Jadi, para pedagang lebih memilih tetap berdagang di pasar yang lokasinya dekat dengan pemukiman karena faktor lokasi sangat berpengaruh dalam perkembangan pasar hal ini sama dengan penelitian Djojodipuro dalam penelitian (Suryani, 2015) menyatakan bahwa dalam hal pemilihan lokasi pembangunannya, pasar tradisional sebaiknya didirikan pada lokasi yang ramai dan luas. Pendirian pasar pada lokasi yang tidak ada aktivitas perdagangannya, sangat sulit diharapkan akan dikunjungi oleh masyarakat.

Menurut Suryani, 2015; dan Utomo, 2011 
bahwa dalam hal pemilihan lokasi pembangunannya, pasar tradisional sebaiknya didirikan pada lokasi yang ramai dan luas, agar lebih terjamin proses transaksi jual beli sehingga dapat diperhatikan faktor-faktor keramaian lalu lintas, kemungkinan tempat pemberhentian orang untuk berbelanja, keadaan penduduk di lingkungan pasar, keadaan perparkiran dan sebagainya. Sedangkan jumlah penduduk, pendapatan perkapita, distribusi pendapatan, aglomerasi dan kebijaksanaan pemerintah juga sangat mempengaruhi penentuan lokasi suatu kegiatan untuk saat ini lokasi Pasar Lorong Milik merupakan pasar yang cocok, dimana letak pasar yang beredekatan dengan wilayah pemukiman penduduk.

Pasar Lorong Milik ini tidak memiliki koordinasi instansi atau pemerintahan dalam mengelola pasar tersebut jadi dapat disimpulkan bahwa pemerintah tidak mengelola pasar lorong milik hanya saja dari Lembaga Pemberdayaan Masyarakat (LPM) yang bertugas sebagai petugas keamanan untuk menertibkan kendaraan baik roda dua dan roda empat serta sebagai pengamanan di sekitar pasar lorong milik dan tidak ada nya sistem pengelolaan pasar di pasar lorong milik karena lapak dan kios semua nya bersifat pribadi dalam hal ini yang membangun kios-kios dan lapak dari penduduk setempat di Lorong Milik.

Pada Partisipasi yang meliputi keikutsertaan dalam koordinasi dan kesadaran pedagang bahwa tidak adanya koordinasi pemerintah dalam melakukan rapat dan sosialisaisi mengenai relokasi pasar, karena tidak ada yang mengkoordinir maka para pedagang bersifat acuh tak acuh mengenal relokasi pasar sehingga menimbulkan penolakan dalam relokasi pasar tersebut.

\section{SIMPULAN}

Berdasarkan hasil penelitian yang telah dilakukan, peneliti dapat menyimpulkan bahwa resistensi pedagang terhadap relokasi pasar dari pasar Mariana ke pasar Prajen dikarenakan dari anggaran dana tidak ada bantuan dari pemerintah dalam masa transisi dari pasar lama ke pasar baru setelah itu dari segi infrastruktur yang meliputi aksebilitasi baik jalan dan transportasi itu tidak ada angkutan umum menuju lokasi pasar baru dan tidak ada koordinir dari pemerintah untuk sosialisasi mengenai relokasi pasar serta kurangnya kesadaran para pedagang akan hal relokasi pasar tersebut. Jadi para pedagang lebih memilih tetap berdagang di pasar yang lokasinya dekat dengan pemukiman karena faktor lokasi sangat berpengaruh dalam perkembangan pasar, untuk saat ini lokasi pasar Lorong Milik merupakan pasar yang cocok, dimana letak pasar yang beredekatan dengan wilayah pemukiman penduduk.

\section{DAFTAR PUSTAKA}

Dewi, Nirmala Mustika. 2015. Resistensi Pedagang Terhadap Implementasi Kebijakan Relokasi Pasar Waru Sidoarjo. Jawa Timur: Jurnal Politik Muda, Vol. 4 No. 1, Januari Maret 2015, 126- 136.

Hidayah, Ayu Ulfiani "Analisis Pelaksanaan Relokasi Pedagang Kaki Lima Di Pasar Simpang Padang Duri Kecamatan Mandau Kabupaten Bengkalis", dalam JOM FISIP Vol. 4 No. 1.

Mahmud. 2011. Metode Penelitian Pendidikan. Bandung : CV Pustaka Setia

Sugiyono.2010. Metode Penelitian Kuantitatif Kualitatif dan $R \& D$. Bandung: Alfabeta.

Suryani, Yosi. 2015. Teori Lokasi Dalam Penentuan Pembangunan Lokasi Pasar Tradisional (Telaah Studi Literatur).Padang. Seminar Nasional Ekonomi Manajemen DanAkuntansi (SNEMA) Fakultas Ekonomi Universitas Negeri Padang Isbn: 978-60217129-5-5.

Utomo, Budi dan Lutfi Muta'ali. 2011. Analisis Potensi Wilayah Untuk Pengembangan Kawasan Perdagangan Di Kota Surakarta Bagian Utara. Tesis. Yogyakarta : Fakultas Geografi

UGM. http://etd.repository.ugm.ac.id/index.php?mo $\mathrm{d}=$ penelitian_detail\&sub=PenelitianDetail\&a $\mathrm{ct}=$ view\&typ=html\&buku_id=52271.

Utomo, Budi. 2017. Penguatan Ekonomi Lokal Menuju Kemandirian Daerah: Studi Kasus Kota Palembang. Palembang: Jurnal Swarnabhumi. Vol. 2 (1): 45-49. Februari 2017. ISSN 2548-5563. E-ISSN 2622-2701 